\title{
Development time and new product sales: A contingency analysis of product innovativeness and price
}

\author{
Fred Langerak • Serge Rijsdijk • Koen Dittrich
}

Published online: 8 April 2009

C The Author(s) 2009. This article is published with open access at Springerlink.com

\begin{abstract}
Opposing theories and conflicting empirical results with regard to the effect of development time on new product sales suggest the need for a contingency analysis into factors affecting this relationship. This study uses a unique combination of accounting and perceptual data from 129 product development projects to test the combined contingency effect of product innovativeness and new product price on the relationship between development time and new product sales. The results show that for radically new products with short development times, price has no effect on new product sales. When the development time is long, price has a negative effect on the sales of radical new products. The findings additionally show that price has no effect on sales for incremental new products with short development times and a negative effect for incremental new products with long development times. Together, these findings shed new light on the relationship between development time and new product sales.
\end{abstract}

Keywords Development time $\cdot$ Product innovativeness $\cdot$ New product price

Many studies posit that shortening the new product's development time brings about an increased level of cohesion among team members which results in fewer mistakes that might cause problems after product launch (see, e.g., Chen et al. 2005). Faster development has also been linked with improved coordination and subsequent reductions in costly work redundancy, errors, and recycling that will cause quality problems after adoption (Harter et al. 2000). Concentration on speed also forces a

F. Langerak $(\bowtie)$

Innovation, Technology Entrepreneurship and Marketing group, School of Industrial Engineering, Eindhoven University of Technology, P.O. Box 513, 5600 MB Eindhoven, The Netherlands e-mail: f.langerak@tue.nl

S. Rijsdijk $\cdot$ K. Dittrich

Rotterdam School of Management, Erasmus University, Rotterdam, The Netherlands 
development team to focus on those elements of a product design that are most relevant for customers (Ali et al. 1995). For these reasons, many studies posit that development time reduction may improve the new product's acceptance by potential users (Kessler and Chakrabarti 1996).

However, there is also recognition that development time reduction may have disadvantages. Attempts to reduce development time may sacrifice necessary market research steps that lead to reduced feature sets or lower performance-price ratios. Besides, an overly tight schedule might push the new product development (NPD) project past the limits of organizational capabilities and result in under-designed products (Vincent 1989). Design errors can also arise from skipping process steps, and having members of speeded up teams chew up the firm's support resources (Langerak et al. 2008). For these reasons speeding up development time may result in compromised product advantage and extensive post-launch product debugging that slow customer acceptance (Crawford 1992).

The contrast between theories advocating the (dis)advantages of shortening development time is also reflected in conflicting empirical results with regard to the effect on new product sales. Several studies show positive results (e.g., Calantone and Di Benedetto 2000; Lynn et al. 1999), some mixed findings (e.g., Ittner and Larcker 1997), and others present no evidence of a relationship (e.g., Dröge et al. 2004; Griffin 2002). Reflecting on these divergent empirical results it seems likely that under some circumstances, development time reduction has a positive effect on new product sales and under other conditions a negative effect.

A contingency analysis may provide new insights into the complex relationship between development time and new product sales (Chen et al. 2005). Prior research has identified product innovativeness as an important contingency factor (e.g., Ali 2000; Langerak and Hultink 2006). These studies show that shortening the development time of radical new products lowers sales revenues. Conversely, they show that shortening the cycle time of incremental new products improves the chance of meeting revenue goals. The rationale for these findings is that radical new projects are typically more difficult, risky, and costly to accelerate than incremental projects (Griffin 1997). As such, radical new projects that are accelerated mostly induce the disadvantages associated with cycle time reduction, while shortening the cycle time of incremental projects typically brings on the advantages.

This study extends these analyses by focusing on the combined contingency effect of product innovativeness and new product price. This is important because the marketing literature is clear about the need to coordinate the development time and product innovativeness decisions with other launch decisions, in particular the new product's price (e.g., Hultink and Robben 1999; Ingenbleek et al. 2004). A penetration price may, for example, be appropriate to reinforce the advantages that accelerated development of incremental new products brings on (Crawford and Di Benedetto 2006). Despite the clear need to coordinate the pricing decision with the product's innovativeness and development time, prior research has mostly studied this decision in isolation. Therefore, our objective is to investigate how new product price influences the sales of radical versus incremental new products with either short or long development times.

To accomplish our aim, we review the marketing and NPD literatures to develop two hypotheses on how product innovativeness and new product price together 
influence the relationship between development time and new product sales. The hypotheses are tested using a unique dataset from 129 completed NPD projects with continued market acceptance from a single firm. The existing development time literature has mostly used survey data across multiple firms and often focused on a single new product per firm. These studies can therefore suffer from problems due to selection and response bias, difficulties in comparing results across firms and industries, and isolating the firm effect from the effect of the new product studied. By using data across many new products in a single firm, this study gets around most of these problems.

The remainder of this article is structured as follows. The next section presents the definitions and hypotheses. The research methodology and model are then presented, followed by the results and their implications. The final section discusses limitations and directions for further research.

\section{Hypotheses}

To be consistent with prior research, we define development time as the elapsed time from the beginning of idea generation, when the firm decided to develop a new product, to market introduction (e.g., Griffin 2002; Kessler and Chakrabarti 1999). To assess product innovativeness, we distinguish between radical versus incremental products. A radical new product is one that incorporates a substantially different technology and requires different marketing skills compared to existing products in the industry (Chandy et al. 2003). An incremental innovation is designed to satisfy a felt market need and uses an existing technology or refinement of it (Min et al. 2006).

Prior research shows that development time reduction worsens a radical new product's acceptance by potential users (e.g., Ali 2000). The rationale is that accelerated development of radical new products usually brings on the disadvantages of development time reduction because radical projects are difficult to plan, risky to execute, and complex to implement (Griffin 1997). These disadvantages negatively affect the benefits that the new product provides to customers. Product advantage may be harmed when skipping development steps sacrifices engineering and market research information that is necessary to get the new product design right (Langerak et al. 2008). An overly tight lead time schedule also raises the probability that design mistakes are made because it pushes the NPD project past the limits of R\&D and marketing capabilities (Agarwal and Bayus 2002). Time budget cuts can also constrain the amount of product advantage achieved and slow down customer acceptance (Calantone and Di Benedetto 2000). Radical products also call for a special sales force, distribution field capacity, or a stand-by plan if problems come up after launch. These requirements may, however, also be warped under pressure of accelerated NPD (Calantone and Di Benedetto 2000). As a result, the radical new product's ability to meet customer needs may be compromised, and customers are likely to adopt a wait-and-see strategy. The launch literature suggests that to surmount these adoption barriers and increase diffusion firms may set a lower price at the moment of launch (Guiltinan 1999). Such a price discount rewards customers for adopting an underdeveloped new product (Crawford and Di Benedetto 2006). 
However, the sales gain of a reduced price is likely to be small in comparison to the sales loss brought on by the compromised advantage of a radical new product that is rushed to market.

In contrast, firms taking more time to develop radical new products are usually able to repress most of the disadvantages associated with cycle time reduction that impair new product benefits (Crawford 1992). These firms avoid the possible problems of an underdeveloped product advantage and extensive post-launch product debugging. Moreover, firms that take more time can better understand the preferences of customers, identify a superior but overlooked product position, and set up a sufficient distribution capacity and sales force. Taking more time also allows firms to better inform customers about their radical new product's advantage. The literature suggests that firms may charge a premium price if the radical new product's advantage supports a higher price (Hultink and Robben 1999). However, charging a premium price is often too costly to firms with longer development times because of the new product's extended break even time (Ali et al. 1995). Firms with lengthier development times have usually incurred higher development costs and by charging a premium price demand is unnecessarily restricted to those customers willing and able to pay a high price. In contrast, charging a low price for a radical new product with a high advantage stimulates demand and expands the potential market beyond high-end customers (Guiltinan 1999). The sales benefits of a reduced price are expected to be significant for radical new products with an uncompromised product advantage (Calantone and Di Benedetto 2000). Moreover, setting a penetration price for products that are kept in development longer helps to drive the volume-related cost decreases that are important for highly advantaged radical new products to become successful.

Based on the above line of reasoning that for radical new products development time reduction results in compromised product advantage, we expect that the sales benefits of a price discount for radical new products with short development times, while potentially significant, is smaller than the sales increase that a reduced price brings about for radical new products with long cycle times. Therefore:

$\mathrm{H}_{1}$ : The negative effect of price on sales is weaker for radical new products with short development times than for radical new product with long development times.

Prior research posits that development time reduction improves the incremental new product's acceptance by potential users (e.g., Langerak and Hultink 2006). The reason is that accelerated development of incremental projects typically brings on the advantages of development time reduction because they can easily be planned and implemented (LaBahn et al. 1996). Faster incremental NPD has been linked with fewer mistakes, improved coordination, and subsequent reductions in costly work redundancy, errors, and recycling that will cause problems after market launch that slow down customer acceptance (Harter et al. 2000). Incremental new products typically refine and modify existing products, so customers can easily identify incremental benefits relative to existing products (Gatignon and Xuereb 1997). The fact that customer needs already exist makes potential users more price sensitive, especially because they have more information at their disposal to evaluate the incremental new product's advantage than just price (Gatignon and Xuereb 1997). 
Moreover, an incremental new product's advantage is likely to erode fast, which has a tempering effect on the upper boundary of price discretion (Monroe 1990). The narrow window of opportunity of incremental new products also favors setting a low price in order to generate sufficient sales (Robertson 1993). In addition, incremental products are often aimed at the largest and often most price-sensitive market segment. A penetration price may increase the appeal of an incremental new product to this segment and boosts new product sales (Ali et al. 1995). These arguments suggest that price reinforces the negative effect that development time has on the sales of incremental new products. Thus:

$\mathrm{H}_{2}$ : Price has a negative effect on the sales of incremental new products, regardless of the development time elapsed.

\section{Research methodology}

\subsection{Research design}

This study focuses on a single firm to eliminate important confounding cross-industry and cross-firm factors as possible explanations for differences in new product sales (Naveh 2007). We do not deny that other factors may be relevant for new product sales. However, the focus of this study is on project-specific differences that cause some new products to sell better than others. Studying one firm helps us to focus on this objective and reduces concerns about internal validity. At the same time, the projects show substantial heterogeneity because they cover seven product lines. Each product line is supported by a different technology platform, and its products are targeted at customers in different markets. While there is no doubt that the use of multiple firms would enhance the external validity of the findings, we chose to emphasize internal validity over generalizability, as our study is the first to investigate the combined contingency effects of new product innovativeness and price.

\subsection{Empirical context}

The firm in this study was the plastics division of one of the largest and most diversified industrial corporations in the world. This $\$ 6$ billion plastic material supplier and distributor serves customers in a variety of industries, including aerospace, automotive, construction, data storage, optical media, medical, electronics, telecommunications, computers, and packaging. The division employs about 10,000 people and operates some 60 manufacturing and technology facilities in 20 countries worldwide. The division launched more than 600 new products across the seven product lines between 2004 and 2006.

\subsection{Data}

The population for the study was 129 of these new product introductions. To ensure group size equivalence, the sample consisted of 64 incremental and 65 radical new products. We used the firm's database to obtain information on each new product's 
development time, average selling price, unit sales volume, introduction date, and the product line to which the new product belongs. Additional binary data on product innovativeness $(0=$ incremental; $1=$ radical $)$ and two control variables with a recognized influence on new product sales volume-namely, whether the new product was initiated through market pull or technology push $(0=$ push; $1=$ pull $)$ and whether lead users were involved in the NPD process $(0=$ not involved; $1=$ involved $)$-were compiled by asking two managers (i.e., the product line manager and the industry manager) to independently code each new product. The proportion of interjudge agreement was $94 \%$ for new product innovativeness, $98 \%$ for market pull, and $100 \%$ for lead user involvement. Disagreements were resolved through discussion.

We also externally validated the managerial classification on product innovativeness by asking an industry expert to rate the innovativeness of a subsample of 87 new products. The expert considered himself knowledgeable on only 66 of these new products. Subsequently, he was asked to rate the degree of innovativeness of only these new products on a five-point scale. The expert had no knowledge about the fact that the managers classified 38 of these 66 new products as incremental and 28 as radical. A $t$ test revealed a significant $(p<0.05)$ difference between the expert's mean rating of 1.18 for the 38 new products that the managers classified as incremental and his average rating of 4.46 for the 28 new products that the managers classified as radical. Table 1 provides an overview of all variables and their sources.

The new product's launch date enabled us to compute the number of weeks that the product had been on the market (on average 63.64 weeks with a SD of 50.43). The new product's sales volume encompassed the cumulative unit sales from the introduction date to the start of the third quarter of 2006. To address any differential timing effects

Table 1 Conceptual variables and measures

\begin{tabular}{|c|c|c|}
\hline $\begin{array}{l}\text { Conceptual } \\
\text { variable }\end{array}$ & Measure & Source \\
\hline Development time & $\begin{array}{l}\text { Elapsed time in weeks from the beginning of idea generation, when } \\
\text { the firm decided to develop a new product, to market introduction }\end{array}$ & Firm database \\
\hline New product price & $\begin{array}{l}\text { The new product's average selling price in dollars between market } \\
\text { introduction and the start of the 3rd quarter of } 2006\end{array}$ & Firm database \\
\hline $\begin{array}{l}\text { Cumulative new } \\
\text { product sales }\end{array}$ & $\begin{array}{l}\text { Cumulative new product sales in units from introduction date to } \\
\text { start of the 3rd quarter of } 2006\end{array}$ & Firm database \\
\hline $\begin{array}{l}\text { New product } \\
\text { launch date }\end{array}$ & The date on which the new product was introduced into the market & Firm database \\
\hline $\begin{array}{l}\text { Product } \\
\text { innovativeness }\end{array}$ & $\begin{array}{l}\text { The new product incorporates a different technology and requires } \\
\text { different marketing skills compared to existing products in the } \\
\text { industry (yes/no) }\end{array}$ & $\begin{array}{l}\text { Managerial } \\
\text { classification }\end{array}$ \\
\hline $\begin{array}{l}\text { Lead user } \\
\text { involvement }\end{array}$ & Lead user involvement in the development process (yes/no) & $\begin{array}{l}\text { Managerial } \\
\text { classification }\end{array}$ \\
\hline Pull or push & $\begin{array}{l}\text { New product development initiated primarily through market pull } \\
\text { or technology push? }\end{array}$ & $\begin{array}{l}\text { Managerial } \\
\text { classification }\end{array}$ \\
\hline Quarter dummies & $\begin{array}{l}\text { The quarter in which the new product was introduced in the market } \\
\text { ranging from the 1st quarter of } 2004 \text { to the start of the 3rd quarter } \\
\text { of } 2006 \text {. }\end{array}$ & Computed \\
\hline
\end{tabular}


for new products introduced in the early part of the study, relative to those introduced later in the study period, we decided to compute quarter dummies, based on the new product's launch date, which were additionally used as control variables. In the analyses, we left out the quarter dummy representing the first quarter making it the reference quarter for the effects of the remaining nine quarter dummies. Eight (out of ten) quarter dummies were not significantly related to product innovativeness and the quarter dummy for the third quarter $(r=-0.28, p<0.01)$ and the dummy for the fifth quarter $(r=0.26, p<0.01)$ both had significant but opposite relationships with product innovativeness. These correlations also suggest that there is no systematic relationship between time and product innovativeness. Table 2 provides an overview of the correlations among the key variables and their means and SDs.

\section{Model}

\subsection{Model specification}

Equation (1) was used to test the significance of the moderating effects that we have hypothesized. We propose that the effect of price on sales depends on the level of product innovativeness and that development time acts as a moderator on this interaction between product innovativeness and price. Hence, the equation includes a three-way interaction term. In order to properly test this three-way interaction, the three lower-order two-way interaction terms and the main effects should be included in the model as well (Aiken and West 1996). The equation also includes control variables and is represented as follows:

$$
\begin{aligned}
S_{i}= & \beta_{0}+\beta_{1} \sum_{i} X_{j}+\beta_{12} D T_{i}+\beta_{13} P I_{i}+\beta_{14} P_{i}+\beta_{15}\left(D T_{i} \times P I_{i}\right) \\
& +\beta_{16}\left(D T_{i} \times P_{i}\right)+\beta_{17}\left(P I_{i} \times P_{i}\right)+\beta_{18}\left(D T_{i} \times P I_{i} \times P_{i}\right)+\varepsilon_{i}
\end{aligned}
$$

Where:

$X_{j} \quad$ control variables (quarter dummies, lead user involvement, and market pull)

$S \quad$ cumulative sales

\begin{tabular}{|c|c|c|c|c|c|c|c|c|}
\hline & & Mean & S.D. & 1. & 2. & 3. & 4. & 5. \\
\hline 1. & Development time & 63.64 & 50.43 & - & & & & \\
\hline 2. & Product innovativeness & 0.49 & 0.50 & $-0.23 * *$ & - & & & \\
\hline 3. & New product price & 7.14 & 5.00 & 0.14 & -0.02 & - & & \\
\hline 4. & Lead user involvement & 0.48 & 0.50 & 0.05 & -0.10 & -0.04 & - & \\
\hline 5. & Market pull & 0.50 & 0.50 & -0.07 & $0.21 *$ & 0.05 & $-0.61 * *$ & - \\
\hline 6. & Cumulative sales volume & 242.55 & 484.75 & 0.12 & 0.04 & $-0.19 *$ & $0.22 *$ & -0.10 \\
\hline
\end{tabular}

Table 2 Means, SDs, and correlation for key constructs

${ }^{*} p<0.05 ; * * p<0.01$ 
DT development time

PI product innovativeness

$P \quad$ price.

For the testing of $\mathrm{H}_{1}$, we conducted a slope difference test (Dawson and Richter 2006), and for testing $\mathrm{H}_{2}$, we conducted simple slope tests (Aiken and West 1996). Equation (2) shows how the $t$ value for the slope difference test was computed.

$$
t \text { value for the slope difference test }=\frac{b_{\text {radical }, \text { short }}+b_{\text {radical }, \text { long }}}{\sqrt{s_{1616}+s_{1818}+2 s_{1618}}}
$$

where:

$b_{\text {radical,short }}$ the simple slope for the effect of price on sales for radical new products with short development times

$b_{\text {radical,long }}$ the simple slope for the effect of price on sales for radical new products with long development times

$s \quad$ (co)variance, where, for example, $s_{1616}$ is the variance of the parameter estimate $\beta_{16}$, and $s_{1618}$ is the covariance between parameter estimates $\beta_{16}$ and $\beta_{18}$.

Equation (3) shows how the four simple slopes for the effect of price on sales for the different levels of product innovativeness and development time were computed. Equation (4) shows how the SE of this slope was computed. The $t$ value for a simple slope test was computed by dividing the simple slope with the standard error.

Simple slope of price on sales $=\beta_{14}+\beta_{16} D T_{i}+\beta_{17} P I_{j}+\beta_{18}\left(D T_{i} \times P I_{j}\right)$

Standard error for simple slope of price on sales

$$
=\sqrt{\begin{array}{l}
s_{1,414}+D T^{2} \times s_{1,616}+P I^{2} \times s_{1,717}+D T^{2} \times P I^{2} \times s_{1,818}+2 \times D T \times s_{1,416} \\
+2 \times P I \times s_{1,417}+2 \times D T \times P \times s_{1,418}+2 \times D T \times P I \times s_{1,617}+2 \times P I \\
\times D T^{2} \times s_{1,618}+2 \times P I^{2} \times D T \times s_{1,718}
\end{array}}
$$

where:

DT development time

$i \quad$ level of development time $(-1=$ low (short development time), $1=$ high (long development time))

PI product innovativeness

$j \quad$ level of product innovativeness $(0=$ low (incremental products $), 1=$ high (radical products))

$s \quad$ (co)variance, where, for example, $s_{1414}$ is the variance of the parameter estimate $\beta_{14}$, and $s_{1416}$ is the covariance between parameter estimates $\beta_{14}$ and $\beta_{16}$. 


\subsection{Model estimation}

We used hierarchical moderated regression analysis to estimate the model. To minimize concerns about product line differences affecting the estimation results, we standardized the data by forcing the variables to have a mean of zero and a SD of 1 within each product line prior to analysis. Table 3 (model 1) shows that the control variables explain $19 \%$ of the variance in new product sales. Adding the independent variables in model 2 increased the $R^{2}$ to $27 \%(\Delta F=4.045, p<0.01)$. The interaction terms, which were added in model 3 , resulted in a further significant increase of the $R^{2}$ to $44 \%(\Delta F=8.438, p<0.01)$. The $F$ value in each model was significant at $p<0.01$, which means that each regression model as a whole has statistically significant predictive capability. The highest variance inflation factor across the three models was 2.73, and the maximum condition index was 9.56, indicating that multicollinearity was not a serious problem (Belsley et al. 1980; Hair et al. 1998).

\section{Results}

\subsection{Hypothesis testing}

The interaction between development time, product innovativeness, and new product price is negatively related to new product sales $\left(b_{18}=-0.78, p<0.01\right)$. The slope difference test (Dawson and Richter 2006) shows that for radical new products with short development times, the effect of price is significantly weaker than for radical new products with long development times $(t$ value $=-4.168, p<.01)$. Thus, $\mathrm{H}_{1}$ is supported. Simple slope tests show that price has no significant effect on new product sales for radical products with short development times (simple slope, $\left.b_{\text {radical, short }}=-0.08, p=0.41\right)$ and that when the development time is long, price has a negative effect on the sales of radical new products (simple slope, $b_{\text {radical, long }}=-1.72$, $p<0.05)$. Figure 1a graphically represents the two slopes for the group of radical new products. The results further show that price has no significant effect on sales for incremental new products with short development times (simple slope, $b_{\text {incremental, short }}=-0.13, p=0.16$ ). Price has however a negative effect on sales for incremental new products with long development times (simple slope, $b_{\text {incremental, long }}=$ $-0.20, p<0.05)$. Figure $1 \mathrm{~b}$ graphically shows the slopes for the incremental new products. These findings provide partial support for $\mathrm{H}_{2}$ because price was expected to have a negative effect on sales for incremental new products regardless of the development time elapsed.

The results of model 3 additionally show that the interaction between development time and product innovativeness is positively related to new product sales $\left(b_{15}=0.85, p<0.01\right)$. This finding is consistent with prior studies investigating the contingency effect of product innovativeness (Ali 2000; Langerak and Hultink 2006). The results also reveal that lead user involvement $\left(b_{10}=0.53, p<0.01\right)$ and market pull $\left(b_{11}=0.40, p<0.05\right)$ exert positive effects on new product sales. These findings are consistent with prior research showing that customer input in NPD improves the probability of new product success (Henard and Szymanski 2001). The results further show that, in line with what could be expected, most quarter dummies 
Table 3 Estimation results of the effects of development time, product innovativeness, and new product price on cumulative sales volume

\begin{tabular}{|c|c|c|c|c|}
\hline Variables & & Model 1 & Model 2 & Model 3 \\
\hline \multicolumn{5}{|l|}{ Control variables } \\
\hline Constant & $\left(b_{0}\right)$ & 0.21 & 0.16 & -0.22 \\
\hline Dummy 2nd quarter & $\left(b_{1}\right)$ & $-0.89^{*}$ & $-1.17 * *$ & $-0.93 * *$ \\
\hline Dummy 3rd quarter & $\left(b_{2}\right)$ & $-0.61 * *$ & $-0.71 * *$ & -0.36 \\
\hline Dummy 4th quarter & $\left(b_{3}\right)$ & $-0.73 * *$ & $-0.87 * *$ & -0.41 \\
\hline Dummy 5th quarter & $\left(b_{4}\right)$ & -0.03 & 0.00 & 0.30 \\
\hline Dummy 6th quarter & $\left(b_{5}\right)$ & $-0.93 * *$ & $-0.79^{*}$ & -0.38 \\
\hline Dummy 7 th quarter & $\left(b_{6}\right)$ & $-0.91 * *$ & $-0.98 * *$ & $-0.80 * *$ \\
\hline Dummy 8th quarter & $\left(b_{7}\right)$ & -0.39 & -0.39 & 0.28 \\
\hline Dummy 9th quarter & $\left(b_{8}\right)$ & $-0.97 * *$ & $-1.04 * *$ & $-0.65^{*}$ \\
\hline Dummy 10th quarter & $\left(b_{9}\right)$ & $-1.17 * *$ & $-1.03 * *$ & $-0.86^{*}$ \\
\hline Lead user involvement & $\left(b_{10}\right)$ & $0.50 * *$ & $0.48 * *$ & $0.53 * *$ \\
\hline Market pull & $\left(b_{11}\right)$ & $0.18^{*}$ & 0.19 & $0.40 * *$ \\
\hline \multicolumn{5}{|l|}{ Independent variables } \\
\hline Development time & $\left(b_{12}\right)$ & & 0.11 & -0.08 \\
\hline Product innovativeness & $\left(b_{13}\right)$ & & 0.21 & $0.38 * *$ \\
\hline New product price & $\left(b_{14}\right)$ & & $-0.28 * * *$ & $-0.17^{*}$ \\
\hline \multicolumn{5}{|l|}{ Interaction effects } \\
\hline Development time $\times$ product innovativeness & $\left(b_{15}\right)$ & & & $0.85 * * *$ \\
\hline Development time $\times$ new product price & $\left(b_{16}\right)$ & & & -0.04 \\
\hline Product innovativeness $\times$ new product price & $\left(b_{17}\right)$ & & & $-0.73 * * *$ \\
\hline $\begin{array}{l}\text { Development time } \times \text { product innovativeness } \\
\times \text { new product price }\end{array}$ & $\left(b_{18}\right)$ & & & $-0.78 * * *$ \\
\hline$N$ & & 129 & 129 & 129 \\
\hline$d f$ of regression model & & 11,117 & 14,114 & 18,110 \\
\hline$R^{2}$ & & 0.19 & 0.27 & 0.44 \\
\hline Adjusted $R^{2}$ & & 0.12 & 0.18 & 0.35 \\
\hline$F$-statistic & & $2.544 * * *$ & $3.022 * * *$ & $4.838 * * *$ \\
\hline$R^{2}$ change & & & 0.08 & 0.17 \\
\hline$F$ change statistic & & & $4.045^{* * *}$ & $8.438 * * *$ \\
\hline$d f$ of $F$ change statistic & & & 3,114 & 4,110 \\
\hline
\end{tabular}

${ }^{*} p<0.10 ; * * p<0.05 ; * * * p<0.01$

have a negative effect on new product sales, indicating that the cumulative sales of products introduced in the second quarter or later is generally lower than the sales of the products launched in the first quarter of our data.

\subsection{Endogeneity concerns and alternative model specifications}

The specified models included several variables to reduce specification errors. However, there is a chance that development time may be correlated with variables 
a Simple slopes for radical new products

\section{Radical new products}

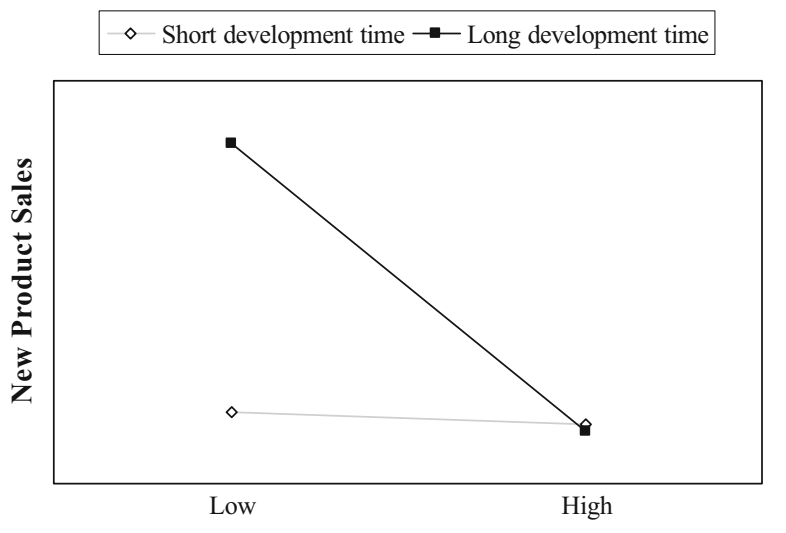

New product price

b Simple slopes for incremental new products Incremental new products

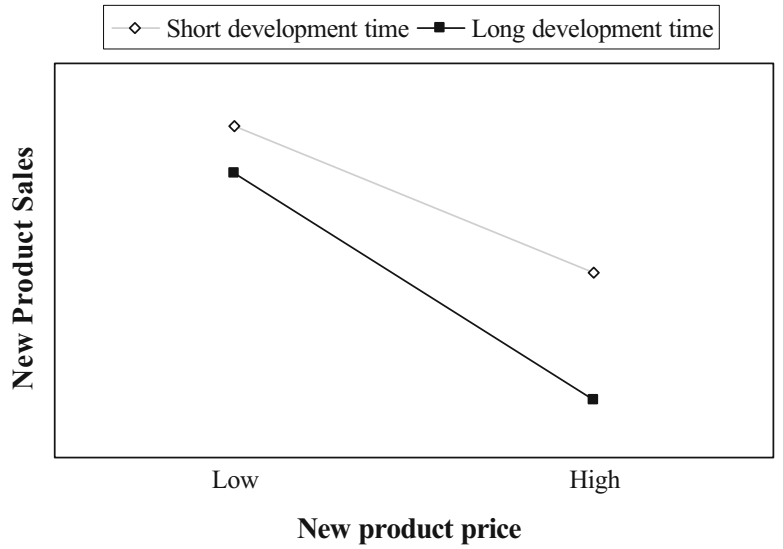

Fig. 1 a Simple slopes for radical new products. b Simple slopes for incremental new products

that were omitted from the specified model or that development time may vary for radical and incremental new products. Usually, it is assumed that radical new products take longer to develop than incremental new products (e.g., Ali 2000; Griffin 2002), although the firm central in our study takes on average shorter to develop radical new products. According to one of the higher managers, employees might devote more time and resources to the development of radical new products than to the development of incremental new products as these radical projects are more challenging.

Unfortunately, data limitations (i.e., the absence of additional instrumental variables in the firm's database) prevented us from conducting a test on the 
exogeneity of development time using model 3. Alternatively, we conducted a Hausman test using a reduced model to investigate the extent to which the firmspecific relationship between product innovativeness and development time may have affected our results. To this end, we first specified a model in which we regressed development time on the quarter dummies, product innovativeness, and the lead user involvement and market pull dummies. Next, we regressed cumulative sales on development time, product innovativeness, new product price, and the residuals from the first model. The results show that there was a nonsignificant negative effect of the residuals on cumulative sales $\left(b_{\text {residuals }}=-0.30, p=0.18\right)$, which rejects the hypothesis that development time is endogenous.

We also estimated a model in which we replaced the quarter dummies with a single variable representing the number of weeks that the new product had been on the market. The results show that the coefficients of interest are not substantially different from the ones reported in model 3 . The fit of the alternative model $\left(R^{2}=0.31\right.$, Adj. $R^{2}=0.26, F$ value $\left.(10,118)=5.427\right)$ is, however, significantly $(p<0.01)$ worse than that of model 3 . Finally, we also estimated a model in which we used the average weekly sales as a dependent variable to control for the varying duration effects of new products. The results of the simple slope tests are similar to the ones reported above, but the model fit is worse $\left(R^{2}=0.17, \operatorname{Adj} . R^{2}=0.10\right.$, $F$ value $(9,119)=2.628)$.

\section{Discussion and implications}

This study is part of a continuing effort by Ali (2000) and others to shed light on the relationship between development time and new product performance. The present study broadens the theory on development time-based competition by incorporating new product price in the relationship between development time, product innovativeness, and new product sales. It also provides evidence that firms need to coordinate the pricing decision with other launch decisions, in particular the new product's innovativeness and development time decisions.

Although the results of this study are not strictly normative, our empirical findings provide three specific managerial insights. First, the results show that price has no effect on sales for radical new products with short development times. This finding makes clear that the disadvantages associated with cycle time reduction cannot be resolved by charging a penetration price that rewards customers for compromised product advantage (Calantone and Di Benedetto 2007). These radical new products simply do not meet customer requirements, which is a dominant driver of new product success, due to the hidden costs of accelerated NPD. Second, the finding that price has a negative effect on the sales of radical new products with long development times conforms to our expectations. Charging a high price is clearly too costly to firms taking more time to develop radical new products as the new product's break-even time is extended (Ali et al. 1995), and demand is unnecessarily restricted to those customers willing and able to pay a high price (Guiltinan 1999). Third, the results show that price has no effect on sales for incremental new products with short development times. This unexpected finding sheds new light on conventional wisdom that favors setting a low price for incremental new products 
that are sped to the market. An explanation may be that for incremental new products, the pricing decision is subservient to the development time decision and that getting incremental new products to market as quickly as possible is what truly counts to ensure sufficient sales. Obviously, more in-depth research is required on this issue. The result that new product price negatively affects sales for incremental new products with long development times conforms to conventional wisdom. This finding demonstrates that a low price is perhaps the only feasible option to lift sales for new products with a minor advantage over existing products that have taken (too) long to develop.

\section{Limitations and further research}

This study has several limitations. First, we must acknowledge the possibility of endogeneity in development time affecting our estimation results because the firm being studied systematically emphasized radical products relative to incremental products for faster development. Second, we only considered new products from one firm which warrants caution regarding the generalizability of the findings. However, it allowed us to use objective data on development time, new product price, and unit sales not available from larger intra- and inter-industry studies. Third, we must recognize the drawback of using classification data for lead user involvement, push or pull and product innovativeness, despite the external validation of the innovativeness classification for 66 products. Fourth, we only had the new product's cumulative unit sales at our disposal. Weekly sales data would have enabled us to estimate new product sales curves, which would yield more precise insights into if and how the interaction between development time, innovativeness, and price changes over time. Fifth, we used a price measure that reflects an average selling price. To the extent that new products are sold to key accounts at a discount and price changes over time, especially relative to competitors' prices, some bias may inhere in our findings. Sixth, the absence of an effect of new product price on sales for radical new products with short development times may be attributed to order of entry effects. Data limitations prevented us from controlling for this effect. Finally, we restricted our attention to new products with continued market acceptance. None of the new products were withdrawn from the market in the observed study period. Different results could surface if the time period under consideration was extended.

Acknowledgments The authors thank the editor and two anonymous reviewers for their constructive comments that helped in shaping this article. They also acknowledge a division of a large industrial corporation for providing the data and Jaap Dekker for his help in the data collection process. This article has benefited from the comments of Erik Jan Hultink in earlier stages of development.

Open Access This article is distributed under the terms of the Creative Commons Attribution Noncommercial License which permits any noncommercial use, distribution, and reproduction in any medium, provided the original author(s) and source are credited. 


\section{References}

Agarwal, R., \& Bayus, B. L. (2002). The market evolution and sales take-off of product innovations. Management Science, 48(8), 1024-1041. doi:10.1287/mnsc.48.8.1024.167.

Aiken, L. S., \& West, S. G. (1996). Multiple regression, testing and interpreting interactions. Thousand Oaks: Sage.

Ali, A. (2000). The impact of innovativeness and development time on new product performance for small firms. Marketing Letters, 11(2), 151-163. doi:10.1023/A:1008142823872.

Ali, A., Krapfel, R., Jr., \& LaBahn, D. W. (1995). Product innovativeness and entry strategy: impact on cycle time and break-even time. Journal of Product Innovation Management, 12(1), 54-69. doi:10.1016/0737-6782(94)00027-D.

Belsley, D. A., Kuh, E., \& Welsch, R. E. (1980). Regression diagnostics: Identifying influential data and sources of collinearity. New York: John Wiley and Sons.

Calantone, R. J., \& Di Benedetto, C. A. (2000). Performance and time to market: Accelerating cycle time with overlapping stages. IEEE Transactions on Engineering Management, 47(2), 232-244. doi:10.1109/17.846790.

Calantone, R. J., \& Di Benedetto, C. A. (2007). Clustering new product launches by price and launch strategy. Journal of Business and Industrial Marketing, 22(1), 4-19. doi:10.1108/ 08858620710722789.

Chandy, R. K., Prabhu, J. C., \& Antia, K. D. (2003). What will the future bring? Dominance, technology, expectations, and radical innovation. Journal of Marketing, 67(3), 1-18. doi:10.1509/ jmkg.67.3.1.18652.

Chen, J., Reilly, R. R., \& Lynn, G. S. (2005). The impacts of speed-to-market on new product success, the moderating effects of uncertainty. IEEE Transactions on Engineering Management, 52(2), 199-212. doi:10.1109/TEM.2005.844926.

Crawford, C. M. (1992). The hidden costs of accelerated product development. Journal of Product Innovation Management, 9(3), 188-199. doi:10.1111/1540-5885.930188.

Crawford, C. M., \& Di Benedetto, C. A. (2006). New products management (8th ed.). IL, Irwin-McGraw Hill: Burr Ridge.

Dawson, J. F., \& Richter, A. W. (2006). Probing three-way interactions in moderated multiple regression: Development and application of a slope difference test. The Journal of Applied Psychology, 91(4), 917-926. doi:10.1037/0021-9010.91.4.917.

Dröge, C., Jayaram, J., \& Vickery, S. K. (2004). The effects of internal and external integration practices on time-based performance and overall firm performance. Journal of Operations Management, 22(6), 557-573. doi:10.1016/j.jom.2004.08.001.

Gatignon, H., \& Xuereb, J. M. (1997). Strategic orientation of the firm and new product performance. JMR, Journal of Marketing Research, 34(1), 77-90. doi:10.2307/3152066.

Griffin, A. (1997). The effect of project and process characteristics on product development cycle time. JMR, Journal of Marketing Research, 34(1), 24-35. doi:10.2307/3152062.

Griffin, A. (2002). Product development cycle time for business-to-business products. Industrial Marketing Management, 31(4), 291-304. doi:10.1016/S0019-8501(01)00162-6.

Guiltinan, J. P. (1999). Launch strategy, launch tactics, and demand outcomes. Journal of Product Innovation Management, 16(6), 502-529. doi:10.1016/S0737-6782(99)00013-2.

Hair, J. F., Anderson, R. E., Tatham, R. L., \& Black, W. C. (1998). Multivariate data analysis (5th ed.). Upper Saddle River, NJ: Prentice Hall.

Harter, D. E., Krishnan, M. S., \& Slaugther, S. A. (2000). Effects of process maturity on quality, cycle time, and effort in software product development. Management Science, 46(4), 451-466. doi:10.1287/ mnsc.46.4.451.12056.

Henard, D. J., \& Szymanski, D. M. (2001). Why some new products are more successful than others. JMR, Journal of Marketing Research, 38(3), 362-375. doi:10.1509/jmkr.38.3.362.18861.

Hultink, E. J., \& Robben, H. S. J. (1999). Launch strategy and new product performance: An empirical examination in The Netherlands. Journal of Product Innovation Management, 16(6), 545-556. doi:10.1016/S0737-6782(99)00015-6.

Ingenbleek, P., DeBruyne, M., Frambach, R. T., \& Verhallen, T. M. M. (2004). Successful new product pricing practices: A contingency approach. Marketing Letters, 14(4), 289-305. doi:10.1023/B: MARK.0000012473.92160.3d.

Ittner, C. D., \& Larcker, D. F. (1997). Product development cycle time and organizational performance. JMR, Journal of Marketing Research, 34(1), 13-23. doi:10.2307/3152061. 
Kessler, E. H., \& Chakrabarti, A. K. (1996). Innovation speed: A conceptual model of context, antecedents, and outcomes. Academy of Management Review, 21(4), 1143-1191. doi:10.2307/ 259167.

Kessler, E. H., \& Chakrabarti, A. K. (1999). Speeding up the pace of new product development. Journal of Product Innovation Management, 16(3), 231-247. doi:10.1016/S0737-6782(98)00048-4.

LaBahn, D. W., Ali, A., \& Krapfel, R. (1996). New product development cycle time: the influence of project and process factors in small manufacturing companies. Journal of Business Research, 36(2), 179-188. doi:10.1016/0148-2963(95)00120-4.

Langerak, F., \& Hultink, E. J. (2006). The impact of product innovativeness on the link between development speed and new product profitability. Journal of Product Innovation Management, 23(3), 203-214. doi:10.1111/j.1540-5885.2006.00194.x.

Langerak, F., Hultink, E. J., \& Griffin, A. (2008). Exploring mediating and moderating influences on the links among cycle time, proficiency in entry timing, and new product profitability. Journal of Product Innovation Management, 25(4), 370-385. doi:10.1111/j.1540-5885.2008.00307.x.

Lynn, G. S., Skov, R. B., \& Abel, K. D. (1999). Practices that support team learning and their impact on speed to market and new product success. Journal of Product Innovation Management, 16(5), 439454. doi:10.1016/S0737-6782(98)00071-X.

Min, S., Kalwani, M. U., \& Robinson, W. T. (2006). Market pioneer and early follower survival risk: A contingency analysis of really new versus incrementally new product-markets. Journal of Marketing, 70(1), 15-33. doi:10.1509/jmkg.2006.70.1.15.

Monroe, K. (1990). Pricing: Making profitable decisions. New York: McGrawhill.

Naveh, E. (2007). Formality and discretion in successful R\&D projects. Journal of Operations Management, 25(1), 110-125. doi:10.1016/j.jom.2006.02.004.

Robertson, T. S. (1993). How to reduce market penetration cycle times. Sloan Management Review, 35(1), 87-96.

Vincent, G. (1989). Managing new product development. New York: Van Nostrand Reinhold. 